\title{
Quality Assessment of Groundwater Sources of Potable Water in Owerri, Imo State, Nigeria
}

\author{
Boniface Chidi Okoro', Regina Akudo Uzoukwu² ${ }^{2}$, Christopher Kparmekpo Ademe1 \\ ${ }^{1}$ Department of Civil Engineering Technology, Federal University of Technology, Owerri, Nigeria \\ ${ }^{2}$ Department of Civil Engineering Technology, Federal Polytechnic Nekede, Owerri, Nigeria \\ Email: bc1okoro@yahoo.com, regina.uzoukwu@gmail.com
}

Received 10 March 2016; accepted 24 March 2016; published 28 March 2016

Copyright (C) 2016 by authors and OALib.

This work is licensed under the Creative Commons Attribution International License (CC BY).

http://creativecommons.org/licenses/by/4.0/

$$
\text { (c) (i) Open Access }
$$

\begin{abstract}
The research investigated the quality of ground waters in boreholes used as potable water (drinking water and other domestic purposes) in Owerri, Imo State, Nigeria. Three boreholes were randomly selected from numerous boreholes in Owerri. Water analyses were carried out for their physicochemical parameters, major ions, nutrients and bacteriological quality. The obtained average values from the analyses are: total iron $(\mathrm{Fe})(\mathrm{mg} / \mathrm{L})=0.03, \mathrm{pH}=5.9$, nitrate $(\mathrm{mg} / \mathrm{L})=3.0$, nitrate $(\mathrm{mg} / \mathrm{L})=$ nil. The observed average values were compared with standard values of the World Health Organization (WHO) for potable water. The results showed that the groundwater qualities from the selected borehole samples are generally low in dissolved constituents and therefore it recommends that borehole waters from areas around owerri are generally acceptable as potable water for human consumption.
\end{abstract}

\section{Keywords}

Quality Assessment, Potable Water, Groundwater, Borehole Water, Physical and Chemical Analyses

Subject Areas: Civil Engineering

\section{Introduction}

\subsection{Water}

Water is an essential natural resource that is vital for ecosystem functioning and human well-being. Water is an essential component of life. Globally, there is a drawback in its availability and this is increasing and duplicating

How to cite this paper: Okoro, B.C., Uzoukwu, R.A. and Ademe, C.K. (2016) Quality Assessment of Groundwater Sources of Potable Water in Owerri, Imo State, Nigeria. Open Access Library Journal, 3: e2445.

http://dx.doi.org/10.4236/oalib.1102445 
itself thereby intensifying the struggle for scarce water resources as discussed by Olukanni et al. [1]. Water is a resource under considerable pressure. Water is a basic necessity. It is required for human and animal consumption. It is needed for the growth of agricultural produce which sustains life on the earth. Water is used for various other purposes such as hydropower development, navigation and recreation. If water is properly harnessed and utilized, it can be a boon and of immense value to humanity. However, if the water is not properly controlled, it may be a curse and cause destruction and misery. Water quality management is an important phase of the water-resources engineering, without which pollution may threaten its utility as discussed by Arora [2]; Gupta \& Gupta [3].

\subsection{Potable Water}

According to WiseGEEK [4] potable water which is also called drinking water is water which is fit for consumption by humans and other animals. Potable water is water safe enough for drinking and food preparation. Water is essential for life. The amount of drinking water required is variable. It depends on physical activity, age, health issues, and environmental conditions as stated by Grandjean [5]. Globally, in 2012, 89\% of people had access to water suitable for drinking. Nearly 4 billion had access to tap water while another 2.3 billion had access to wells or public taps. About 1.8 billion people still use an unsafe drinking water source which may be contaminated by faeces. Assurance of drinking water safety is a foundation for the prevention and control of waterborne diseases.

\subsection{Ground Water}

Groundwater refers to the water that occurs below the earth surface. The main source of ground water is infiltration. The infiltrated water after meeting the soil moisture deficiency percolates deeply and becomes ground water. Groundwater is free from pollution and is very useful for domestic use in small towns and isolated farms. It can be made available at a small capital cost and also at least possible time. Ground water has been an important water resource throughout the ages. Like any other natural resource, groundwater is also not unlimited. Gbadebo \& Akinhanmi [6] stated that maintenance of groundwater resources is a must to every home that consumes water. Reddy [7] stated that groundwater must be wisely managed and protected against undue exploitation and contamination by pollutants and salt water.

Groundwater pollution is a growing environmental problem, especially in developing countries. The urbanization process threatens the groundwater quality because of the impact of domestic and industrial waste disposal. This results in aquifer deterioration, since some of the waste products, including sewage and cesspool may be discharged directly into the aquifer system. Water soluble wastes and other materials that are dumped, spilled or stored on the surface of the land or in sewage disposal pit can dissolve by precipitation, irrigation waters or liquid wastes and eventually seep through the soil in the unsaturated zone to pollute the groundwater as discussed by AIRBDA [8]. It is important to note that the present of objectionable tastes, odour, colour as well as harmful substances in such water no matter how abundant it is, renders it unsuitable for domestic, industrial and agricultural uses. The assessments of the physical and chemical characteristics of water are important parameters as they may directly or indirectly affect its quality.

\subsection{Purpose of the Study}

Specifically the study was carried out to determine:

- The physicochemical analyses of the groundwater from the selected boreholes in the study area.

- To access the quality of the groundwater from the selected boreholes as potable water in the study area.

- To compare the physicochemical parameter values with World Health Organization (WHO) and Nigerian Standard for Drinking Water Quality (NSDWQ) standards for drinking water.

\section{Materials \& Methods}

\subsection{Project Site}

Imo state is one of the 36 States created in Nigeria with her capital in Owerri and is located between Latitude $5^{\circ} 29^{\prime} 0^{\prime \prime} \mathrm{N}$ and longitude $7^{\circ} 2^{\prime} 0$ "E South-East Nigeria (see Figure 1 \& Figure 2). Owerri which is an urban city 

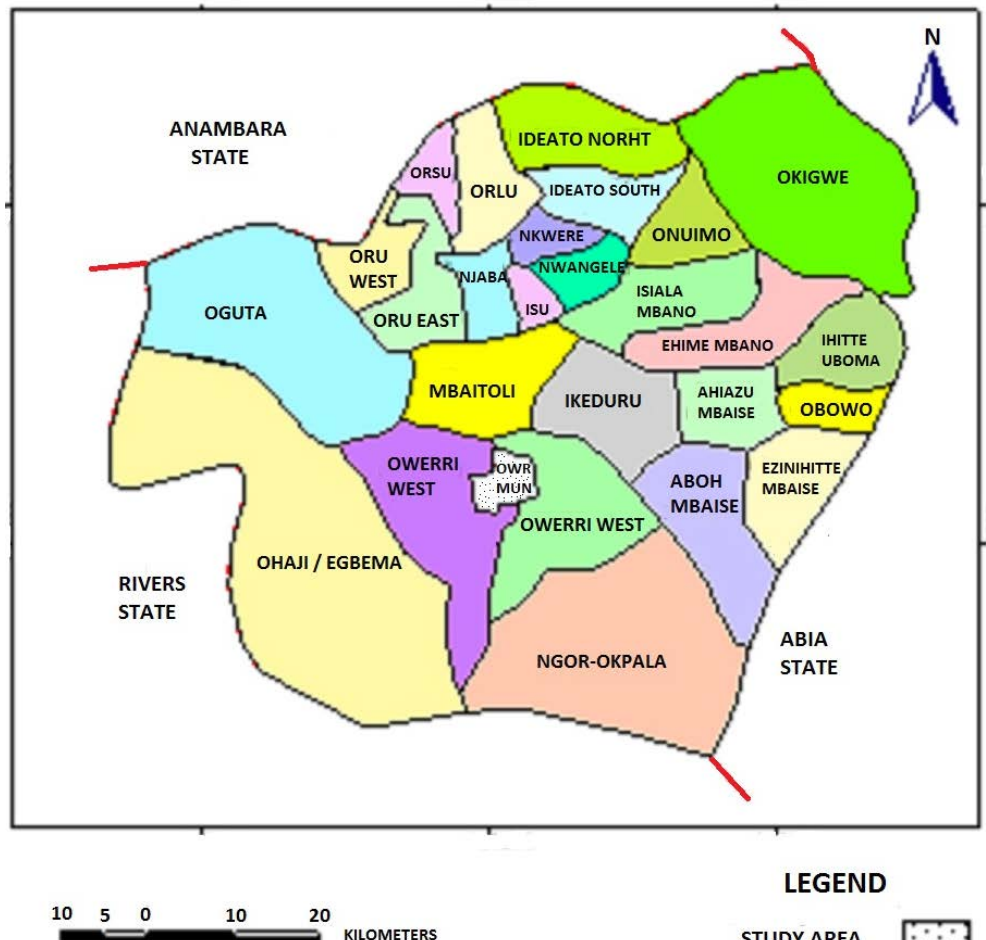

KILOMETERS

LEGEND

STUDY AREA $\because \because: 3$

STATE BOUNDARY

L.G.A BOUNDARY

Figure 1. Map of Imo State showing the position of Owerri municipal.

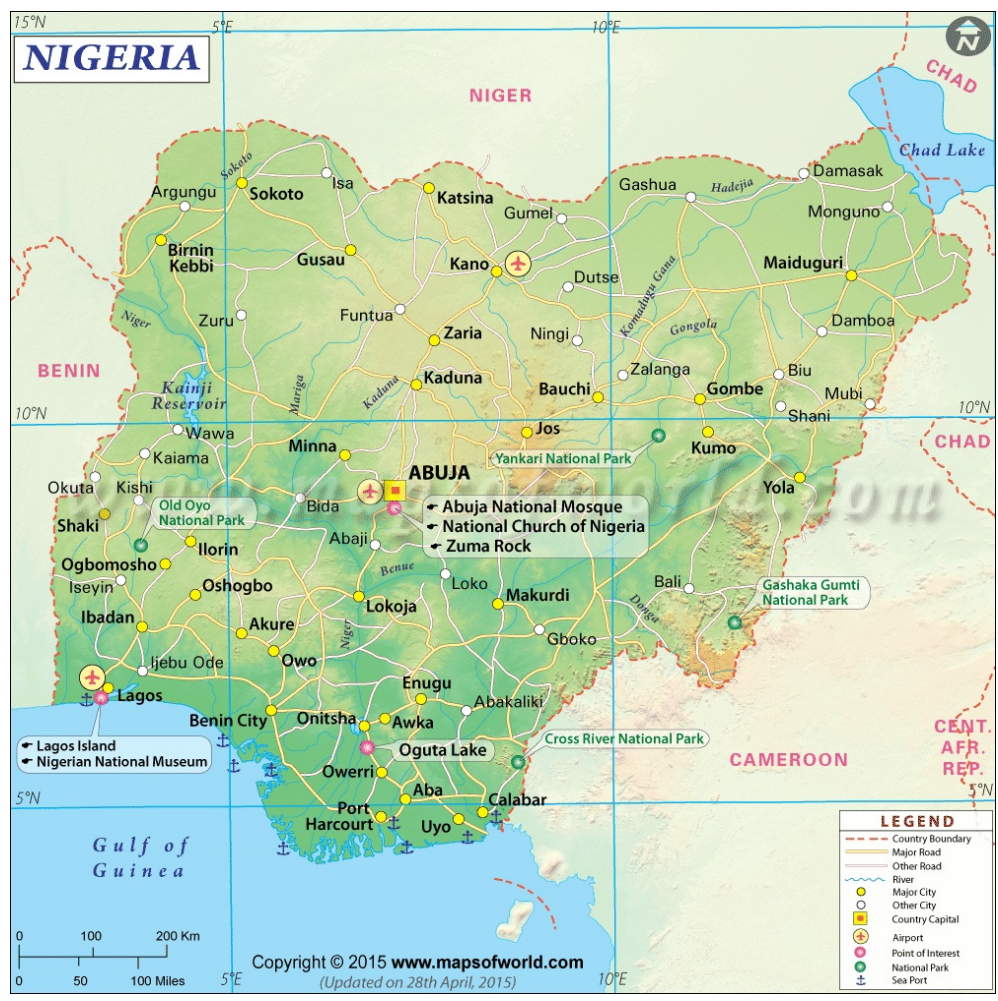

Figure 2. Map of Nigeria showing the position of Owerri. 
has a population of about 2.5 million people. The selected boreholes are located at major and highly populated environs of Fire service, Egbu and Umuoba areas all in Owerri.

\subsection{Water Sampling}

Water samples numbering seventy-five with twenty five samples from each borehole were collected from the selected boreholes in accordance with the procedure recommended in Standard Methods for the examination of water. The parameters tested are: $\mathrm{pH}$, temperature, colour, total dissolved solid, conductivity, hardness, nitrate, nitrite, free chlorine, iron, copper, turbidity and sulphate. The results obtained were compared with World Health Organization (WHO) [9] and Nigerian Standard for Drinking Water Quality (NSDWQ) [10] standards for drinking water.

\subsection{Methods}

\section{Physical and Chemical Analyses}

1) $\mathrm{pH}$ and Temperature

Materials: Suntex $\mathrm{pH}$ and temperature meter, beaker, buffer solution; $7.00 \mathrm{pH}$ for alkalinity and $4.00 \mathrm{pH}$ for acidity, and de-ionized water were used for the analysis.

Procedure: The $\mathrm{pH}$ meter was calibration with standard buffer solution of $\mathrm{pH} 4.0$ and 7.0. Samples of $500 \mathrm{ml}$ each were used to obtain results of $\mathrm{pH}$ and temperature.

2) Total Dissolved Solids (TDS) and Conductivity

Materials: TDS/Conductivity meter, de-ionized water, a beaker and TDS probe were used for the analysis.

Procedure: Samples of $50 \mathrm{ml}$ each were used to obtain values of the conductivity in $\mu \mathrm{s} / \mathrm{cm}$ and the TDS results in $\mathrm{mg} / \mathrm{L}$.

3) Turbidity, Colour and Total Suspended Solids (TSS)

Materials: The following materials were used to obtain turbidity, colour and TSS values: DR2010 data logging spectrophometer, de-ionized water and cell bottle.

Procedure: In the determination of turbidity, colour and TSS, samples of $25 \mathrm{ml}$ each were used to obtain the results with the spectrophometer.

4) Iron and Copper

Materials: To obtain the values for Iron and copper, the following materials were used: Spectrophometer, Samples cell bottles, Ferrower reagent powder pillow and Cuver 1 reagent powder pillow.

Procedure: Samples of $10 \mathrm{ml}$ each were used to obtain results for Iron and copper from the water samples.

5) Nitrate and Free Chlorine

Materials: To obtain the values of nitrate and free chlorine the following materials were used: Hi83200 multiparameter bench photometer, de-ionized water, Hi93728-0 reagent powder pillow for Nitrate and Hi93701-0 reagent powder pillow for Free chlorine.

Methods: Cadmium reduction method as specified by APHA [11] for nitrate and EPA DPD method for free chlorine were used in the determination of the parameters.

\section{Results and Discussion}

\subsection{Results}

The results of the physicochemical parameters of the selected boreholes are shown in Table 1 and Table 2. The values obtained are compared to World Health Organization (WHO) and Nigerian Standard for Drinking Water Quality (NSDWQ) standards for drinking water.

\subsection{Discussion}

Table 1 presented the physicochemical parameters of boreholes water samples, while Table 2 presented a comparison of the average values of the physicochemical parameters of the boreholes water sources and how adequate or acceptable they are to the WHO and NSDWQ standards. The results in Table 1 and Table 2 showed that the selected boreholes samples are very acceptable as sources of drinking water based on WHO and NSDWQ standards except their temperature and turbidity ranges. Although the temperature and turbidity ranges are high, there is no basis for the rejection of water with temperature range above WHO and NSDWQ standards 
Table 1. Physicochemical parameters of borehole water samples in Owerri.

\begin{tabular}{|c|c|c|c|c|c|c|}
\hline $\mathbf{S} / \mathbf{N}$ & Parameters & $\begin{array}{c}\text { Borehole water } \\
\text { at fire service } \\
\text { Area, Owerri }\end{array}$ & $\begin{array}{c}\text { Borehole water at } \\
\text { Umuoba, Uratta } \\
\text { Area, Owerri }\end{array}$ & $\begin{array}{c}\text { Borehole } \\
\text { water at Egbu } \\
\text { Area, Owerri }\end{array}$ & $\begin{array}{c}\text { WHO } \\
\text { standard } \\
{[9]}\end{array}$ & $\begin{array}{c}\text { NSDWQ } \\
\text { NIS.554: [12] } \\
\text { max. permitted } \\
\text { levels }\end{array}$ \\
\hline 1 & Colour (hazen unit) & 3.4 & 3.24 & 3.3 & $5.0-15$ & 15 \\
\hline 2 & Temperature $\left({ }^{\circ} \mathrm{C}\right)$ & 29 & 30 & 29.5 & $27-28$ & Ambient \\
\hline 3 & Turbidity (NTU) & 5.8 & 5.9 & 5.75 & 5 & 5.0 \\
\hline 4 & Copper (mg/L) & Nil & Nil & Nil & Nil & 1 \\
\hline 5 & Iron (mg/L) & 0.02 & 0.01 & 0.03 & 0.3 & 0.3 \\
\hline 6 & Nitrate (mg/L) & 2.0 & 1.86 & 3.0 & 3.0 & 50 \\
\hline 7 & Nitrite (mg/L) & Nil & Nil & Nil & 1.0 & 0.2 \\
\hline 8 & TDS (mg/L) & 18.1 & 16.3 & 17.0 & 500 & 500 \\
\hline 9 & $\mathrm{pH}$ & 5.9 & 5.85 & 5.7 & $6.5-8.5$ & $6.5-8.5$ \\
\hline 10 & Hardness (mg/L) & 3.0 & 2.8 & 2.9 & 500 & 500 \\
\hline 11 & Conductivity ( $\mu \mathrm{s} / \mathrm{cm})$ & 30 & 33 & 31 & 1000 & 1000 \\
\hline 12 & Free residual chlorine (mg/L) & 0.01 & 0.00 & 0.00 & $0.2-5.0$ & $0.2-0.25$ \\
\hline
\end{tabular}

Table 2. Average values of measured parameters of water samples from all the selected boreholes with comparison to WHO and NSDWQ standards.

\begin{tabular}{ccccc}
\hline Parameter & $\begin{array}{c}\text { Average values for } \\
\text { borehole water }\end{array}$ & $\begin{array}{c}\text { WHO } \\
\text { standard [9] }\end{array}$ & $\begin{array}{c}\text { NSDWQ NIS.554: [12] } \\
\text { maximum. permitted Levels }\end{array}$ & Remark \\
\hline Total iron (mg/L) & 0.02 & 0.3 & 0.3 & Fass \\
Turbidity (NTU) & 5.8 & 5.0 & 5.0 & Sail \\
TDS (mg/L) & 17.13 & 500 & 500 & Pass \\
pH & 5.82 & $6.5-8.5$ & $6.5-8.5$ & Fail \\
Temperature ( $\left.{ }^{\circ} \mathrm{C}\right)$ & 29.5 & $27-28$ & 500 & Pass \\
Hardness (mg/L) & 29.0 & 500 & 50 & Pass \\
Nitrate (mg/L) & 2.29 & 3.0 & 0.2 & Pass \\
Nitrite (mg/L) & 0.00 & 1.0 & $0.2-0.25$ & Satisfactory \\
\hline
\end{tabular}

especially when other more suitable supplies are not available, as with the present Government groundwater is now the only source of potable water in Owerri. In terms of total iron, hardness and various forms of nitrogen (nitrate and nitrite) present in the water samples examined were acceptable for human consumption. However, it is important to note that free residual chlorine was satisfactory in the water samples tested.

\section{Conclusion and Recommendations}

\subsection{Conclusion}

The use of boreholes as sources of drinking water for Owerri is good in terms of quality. The pH was within standard limit required. The mean levels for free residual chlorine $(\mathrm{Cl})$, nitrate and nitrite $\left(\mathrm{NO}_{2}^{-}\right)$did not exceed the maximum tolerance limit required by WHO and NSDWQ standards for drinking water.

\subsection{Recommendations}

Based on the study the following recommendations are made: 
1) There should be regular groundwater quality evaluation and monitoring and effective strategies for ensuring that WHO and NSDWQ standards are maintained for every drinking water.

2) However, indiscriminate drilling of boreholes should be checked and regulated in order to protect the public from infiltration of contaminants from soakaway pits; besides, regulators should ensure that WHO and NSDWQ standards are maintained and other government regulations are observed in order to maintain good drinking water quality.

\section{References}

[1] Olukanni, D.O., Busari, A.A. and Ogundeji, J.O. (2015) Water Treatment Trends, Cost and Uses in Ota, Ogun State Nigeria. Journal of Engineering, Science and Technology, 2, 3-7.

[2] Arora, K.R. (2007) Irrigation, Water Power and Water Resources Engineering. 4th Edition, Standard Publishers Distributors, Delhi.

[3] Gupta, B.L. and Gupta, A. (2008) Water Resources Systems and Management. 2nd Edition, A. K. Jain, Delhi.

[4] WiseGEEK (2015) What Is Potable Water? Conjecture Corporation. http://www.wisegeek.com/what-is-potable-water.htm

[5] Grandjean, A.C. (2004) Water Requirements, Impinging Factors, and Recommended Intakes. World Health Organization, 25-34.

[6] Gbadebo, A.M. and Akinhanmi, T.F. (2010) Gender Issues in Management and Use of Groundwater Resources: A Case of Abeokuta Metropolis. Journal of Applied Sciences in Environmental Sanitation, 5, 191-199.

[7] Reddy, P.J.R. (2008) A Textbook of Hydrology. University Science Press, New Delhi.

[8] AIRBDA (2014) Ensuring Acceptable Water Quality in South-Eastern Nigeria. Anambra Imo River Basin Development Authority Owerri.

[9] WHO (2004) WHO Guidelines for Drinking Water Quality: Expert Committee on International Standard for Drinking Water. World Health Organization, Geneva.

[10] NSDWQ (2007) Nigerian Standard for Drinking Water Quality. Committee on Drinking Water Quality in Nigeria, Lagos.

[11] APHA (1998) Standard Methods for the Examination of Water and Wastewater. American Public Health Association, Washington DC.

[12] NIS (2007) Standard for Potable Water. Governing Council, Nigeria Industrial Standard. 